Олена ШАПОВАЛ

\title{
ШЛЯХИ ІНТЕГРАЦІЇ СУЧАСНОЇ УКРАЇНСЬКОЇ СЦЕНОГРАФІЇ В ЄВРОПЕЙСЬКИЙ КУЛЬТУРНИЙ ПРОСТІР
}

У статті досліджуються питання, присвячені визначенню шляхів інтеграиії в європейський культурний простір та виявленню проблем і перспектив розвитку мистецтва сучасної украйнської сиенографіi.

Ключові слова: сиенографія, образотворче мистецтво, фестиваль, конвенція, арт-резидениія.

В статье исследуются вопросы, посвященные определению путей интеграции в европейский культурный проиесс, а также проблемы и перспективы развития современной украинской сценографии.

Ключевые слова: сиенография, изобразительное искусство, фестиваль, конвениия, арт-резиденцุия.

Questions, devoted to determining ways of integration into European culture area and detecting problems and perspectives of developing art of modern Ukrainian scenography, are investigated in this article. They are mainly about determining ways of integration into European culture area and detecting problems and perspectives of developing art of modern Ukrainian scenography, are investigated in this article.

Key words: scenography, art, festival, convention, art residence.

Мистецтво художника-сценографа - невід'ємна частина світу образотворчого мистецтва, де творчу діяльність художника та художника-сценографа можна визначити за певними спільними рисами та закономірними відмінностями. Поняття «образотворче мистецтво», як вид художньої творчості, об'єднує різні види живопису, графіки і скульптури. Втілюючи зорове сприйняття світу на площині або в просторі, образотворче мистецтво обмежене в передачі дії в часі, проте це не означає, що воно зображує світ статично. Образотворче мистецтво здатне передавати рух та показувати життя в розвитку.

Якщо порівняти творчі завдання художник-живописця або графіка та театрального художника, останній має справу не 3 площиною полотна чи паперу, а з простором сцени, в якому створює візуальне сприйняття вистави. Це особливий вид художньої творчості. За словами Олександра Оверчука - художника, скульптора, сценографа: «На відміну від сценографії, декоративно-прикладне мистецтво не працює 3 драматургією і для свого втілення не потребує театру. Покликання ж і функція сценографа неможливі поза драматургією» [6]. Сценограф зобов'язаний мати художню освіту, володіти аналізом драматургії і вміти результат цього аналізу матеріалізувати на сцені в художній формі.

$€$ декілька тлумачень терміна «сценографія». Один із найпоширеніших такий: «Сценографія - вид художньої творчості, що займається оформленням вистави і створенням іiї зображально-пластичного образу, який існує в сценічному часі й просторі». У театральному видовищі до мистецтва сценографії належить усе, що оточує актора (декорації), усе, з чим він має справу грає, діє (це якісь матеріально-речові атрибути) і все, що $є$ на ньому (костюм, грим, маска, інші елементи). При цьому сценографія може використовувати такі виражальні засоби: по-перше, те, що створено природою, по-друге, предмети побуту або виробництва i, по-третє, те, що виникло в результаті творчої діяльності художника (від масок, костюмів, речового реквізиту до живопису, графіки, сценічного простору, світла, динаміки та ін.) $[5,150]$. На думку В. Берьозкіна «сценографію слід розглядати як широке й містке поняття, яке об'єднує всі способи, прийоми та методи оформлення вистави» [2]. Але ми можемо сформулювати головне завдання театрального художника як 
«оформлення простору для сценічної дії і матеріально-речово-світлове забезпечення кожного моменту цієї дії» $[5,153]$.

Сценографія, як оформлення сценічного простору, завжди неповна, це об'єднана «заява» художника, режисера та візуального виконавця про їхній погляд на п’єсу, оперу або танець, яка сприймається аудиторією як спільна праця. Сценограф тісно взаємодіє з режисером, він повинен завжди враховувати його творчий задум і допомогти його реалізовувати. Однак, щоб називатися театральним художником, пасивного втілення ідеї режисера часто буває замало. Якщо художникові-сценографу вистачає досвіду і багатогранності таланту, він може розширити, збагатити режисерську ідею, стати його співавтором. Об'єднуючи зусилля, режисерський та художній задум, можна досягти неймовірного за силою результату. Сценограф - це свого роду архітектор сцени, він повинен розуміти іiі «будову» зсередини, тобто сценограф зобов'язаний знати, як власноруч виготовити декорації і костюми хоча б для того, щоб контролювати процес роботи й бачити, як саме втілюється його творчий задум. Винахідливість, просторове мислення, багата фантазія - все це має бути притаманне театральному художникові. Якоюсь мірою сценограф - це ще і культуролог, який добре знає історію театру, культури, архітектури, костюма.

Проте, незважаючи на суперечності між художниками та художниками-сценографами, бажання бути впізнаваним і успішним на території України та за їі межами, є спільним. I задля його втілення $є$ чимало шляхів презентувати своє мистецтво - гастролюючи, беручи участь у різноманітних українських та міжнародних виставках, проектах, фестивалях тощо. Історичний аналіз української сценографії дає можливість стверджувати, що перетинати кордони та працювати на чужих сценах українські митці-декоратори почали ще у XIX столітті. Декоратором Придворної опери Відня був Т. Яхимович (1836-76); у різних театрах Праги і Парижа - М. Андрієнко-Нечитайло (з 1924-го в теaтpax «Odeon» i «Arc en Ciel»); B. Перебийте - у Кракові (з 1922-го театр «Bagatela») і в Парижі (1926-30); М. Кричевський у «Theatre des Arts» (Париж, 1939) i «Theatre Hebertot» (1942); у Буенос-Айресі (Аргентина) в Національному театрі - О. Климко та ін.

У дослідженні питань теорії та історії сценографії, творчості самих художників-сценографів, ми маємо змогу спиратися на:
- теоретичні праці (К. Станіславського, В. Немировича-Данченка, О. Таїрова, В. Мейєрхольда, Є. Вахтангова, Г. Крега, О. Попова, П. Брука, В. Базанова, Т. Бачеліс, В. Берьозкіна, М. Громова, М. Куніна, В. Листовського, А. Михайлової, С. Серліо, Н. Субботіні, Й. Фуртенбаха, П. Сонреля, Ф. Краніха, І. Ескузовича, А. Петрова, Н. П. Ізвекова);

- історію української сценографії попередніх історичних періодів (І. Вериківська, Г. Веселовська, І. Волицька, М. Гринишина, Н. Єрмакова, Н. Заболотна, Е. Загурська, О. Клековкін, Г. Коваленко, О. Ковальчук, Р. Коломієць, Н. Корнієнко, О. Красильникова, Я. Леоненко, А. Липківська, А. Новикова, О. Попов, Ю. Раєвська, Л. Сокирко, Ю. Станішевський, С. Тобілевич, В. Фіалко, Г. Фількевич, В. Шпаковська та ін.);

- наукові праці з сучасної української сценографії (О. Ковальчук, О. Красильникової, О. Клековкіна, О. Островерх та ін.), а також рецензії, критичні відгуки в періодичних виданнях та на електронних носіях.

У 70-х роках XX століття, коли сценографія ассоціювалася 3 такими славетними іменами, як Давид Боровський, Март Катаєв, Едуард Кочергін, Дмитро Афанасьєв, в Україні - Данило Лідер, Інна Биченкова, Свген Лисик, Мирон Кипріян, Федір Нірод, пошуки відповіді на ці питання у театрознавців були доволі інтенсивними. За словами В. Базанова, «ніколи ще за всю історію театр не розвивався в таких суперечливих формах, як у другій половині XX століття. Ніколи ще не велося так багато дискусій 3 приводу нових форм театрального простору, які відображають, в кінцевому рахунку, сучасний стан театру, його роль у суспільному житті» [1].

Але щодо порушення питань інтеграції української сучасної сценографії у європейський культурний простір фундаментальні дослідження, базовою основою яких стали б вітчизняні матеріали, майже відсутні. Бо ці проблеми не лише теоретичні, а, передусім практичні та надсучасні, а тому потребують аналізу не лише мистецтвознавчого, а й економічного, що грунтується на практичному досвіді арт-менеджменту. Тому актуальність цієї статті не потребує додаткових обгрунтувань. Втім, ми спробуємо визначити проблеми та перспективи розвитку сучасної української сценографії та показати, якими можуть бути шляхи інтеграції сучасних українських художників в європейський культурний простір.

Загальний рівень української сценографії у наш час визначають представники школи Данила Лідера. Можна сказати, що він - фундатор 
Школи української сценографії. Сценографічні пошуки цього покоління художників спираються на фундамент, закладений Лідером, - школу дієвої сценографії. Прорив у розвитку сценографії того часу - це усвідомлення нових завдань художника-сценографа, робота якого стала полягати не в створенні місця дії, а в створенні самої дії. Сценографія стала такою ж важливою частиною спектаклю, як і робота акторів та режисера. Сама дія формувалася під впливом змісту, це була фізична трансформація ідей і тексту п'єси. Учнями Данила Лідера стала низка українських сценографів, серед яких Володимир Карашевський, Марія Левитська, Сергій Маслобойщиков, Ігор Несміянов, Олег Луньов, Андрій Александрович-Дочевський, який продовжив педагогічні традиції та методики Данила Лідера, відродивши в навчальному процесі сучасних молодих сценографів практику залучення студентів до театрального процесу.

Сучасні українські сценографи, які не є учнями Данила Лідера, але також творять сучасну історію сценографії, усім своїм творчим потенціалом поринають у світ новітніх технологій, критеріїв, напрямів. Станіслав Петровський - художник у Національній опері ім. Т. Г. Шевченка, Андрій Злобін - учень Свгена Лисика, який створює унікальні проекти разом із «Київ модерн-балетом», Олександр Білозуб, який з 1997-го по 2001 роки співпрацював з режисером Андрієм Жолдаком у багатьох театрах України, Росії та Європи як актор та художник, а з 2002 року і понині працює художником-постановником 3 режисером Аттілою Віднянським у театрах Угорщини. За його словами «..Національний театр має говорити сучасною мовою» [13], а задля цього художник повинен експериментувати із усіма можливими формами, світлом, звуком. Володимир Стецькович - молодий та амбітний сценограф зі Львова, який у тісній співпраці з художником Львівського академічного театру імені Леся Курбаса Петром Гуменюком опанував нову для себе техніку лінориту (ліногравю́ра (від «лінолеум» і «гравюра») опукла гравюра, створювана вирізуванням малюнка на лінолеумі. За технікою виконання та художніми засобами подібна до ксилографії) [8]. У розумінні Стецьковича «...сучасна сценографія, створюється тут і зараз, не по старих шаблонах, а iз з залученням нових технології, та нового бачення, яке нам диктує сучасність. Проста формула постійно робити щось нове» [9].

Поділяючи загальні визначення дослідників та практичні тенденції сучасних сценографів, у свою чергу наголошуємо, що українська сцено- графія, базуючись на доробках та досвіді попередників, має вміти опановувати величезний сучасний матеріал, технічні можливості та тенденції світового мистецтва сценографії. У своїх роздумах про українське мистецтво та митців, Данило Лідер зауважував, що «...прогрес культури тільки в тому і полягає, щоб зробити людину здатною сприймати чужі світи. Це розуміли Леся Українка, Шевченко, Сковорода, Курбас <...>. Відродження у мистецтві можливе від поєднання глибоких давніх джерел із розвинутою на світовому рівні сучасною культурою» [4]. Наприклад, сучасний європейський театр інтегрується не лише за національними ознаками. Домінантою західних постановок є змішання найрізноманітніших стилів $\mathrm{i}$ подолання кордонів стилістики, простору та гри. Європейська сцена активно використовує елементи кіно, відео, art performance, сучасної музики та літератури, contemporary dance. Отже, розвиваючи думку про співучасть українських митців 3 європейським процесом, маємо підстави стверджувати, що для цього слід перебувати в об'єднаному європейському просторі, лише тоді тенденції стають загальнодоступними. Але, на думку Станіслава Мойсеєва, ми «герметизовані в своєму просторі, і що більше було б інтеграційних спільних проектів, копродукції, то швидше ми б стали співучасниками європейського процесу» [10].

Для образотворчого мистецтва загалом є декілька шляхів інтеграції в Європу - насамперед це європейські гранти, обмінні виставки між художниками та самостійні пошуки можливості виставлятися в музеях та галереях. Але багато митців стикаються 3 фінансовою проблемою, бо в європейський простір пробитися без грошей не так легко, а в порівнянні із європейськими цінами українське образотворче мистецтво коштує небагато. Тому багато художників вирішують не переїздити до Європи, жити в Україні, але продавати свої твори на Заході. Зазначимо, що у колі європейського арт-маркету дуже важливо вміти довести, що твоє мистецтво має продаватися, і вміти переконати, що воно потрібне.

Як уже зазначалось, одним зі шляхів інтеграції виступають європейські гранти. В Європі є арт-резиденції, в яких створені умови для взаємного обміну досвідом і творчого партнерства вільних художників. Більшість із пропозицій зазвичай покриває резидентам чи то значну частку, чи навіть усі витрати, і вже точно кожна обіцяє занурити в атмосферу активного творчого пошуку і продуктивного професійного спілкування. Назвемо деякі 3 найбільш відомих та активно працюючих арт-ре- 
зиденцій. Наприклад, ArtsLink - (США) та ACC Galerie Weimar (Німеччина) спеціалізуються на скульптурі, фото, медіа, мультимедіа, малюванні, живописі, театрі, танцях, перформансах, літератуpi. Арт-резиденція Künstlerhaus Lauenburg (Німеччина) надає стипендії для митців у сфері живопису, графічного дизайну, фотографії, танцю, театру, кіно, візуального й концептуального мистецтва.

Більш імовірні шляхи інтеграції для сценографії - це гастролі, міжнародні театральні фестивалі, спільні міжнародні проекти. Культурне співробітництво як одна з форм взаємодії нашої держави з зарубіжними партнерами дає унікальну можливість познайомитись із національними традиціями, з усім багатством художньо-мистецької спадщини. Театральне мистецтво як частина національної української культури покликане вирішувати завдання щодо подолання культурних кордонів. Театральні фестивалі є однією зі специфічних форм обміну художнім досвідом.

3 багатьох міжнародних мистецьких заходів можна виокремити такі:

- Міжнародний Фестиваль Українського театру «Схід-Захід», заснований у 2014 році Фундацією Масових Видовищ і Шоу-програм та Центром Молоді ім. док. Х. в Кракові. Мета фестивалю - підтримка та популяризація українського театру, представлення найкращих зразків сучасного українського театрального мистецтва в Польщі;

- Міжнародний фестиваль Porto Franko в Україні. Фестиваль включає три напрями: театральний, музичний та візуальний;

- Фестиваль «Драбина» - міжнародний фестиваль недержавного, незалежного і аматорського театру. Відбувається з 2004 року у м. Львові;

- Авіньйонський фестиваль - один з найстаріших театральних фестивалів у Європі, відомий своєю особливою увагою до новаторських постановок. Щороку у фестивалі беруть участь близько сорока спектаклів. Це лабораторія прем'єр і місце дослідження нового як для театральних діячів, так і для глядачів. Театральних діячів і їх проекти відбирає безпосередньо сам художній керівник фестивалю;

- Единбурзький міжнародний фестиваль i Единбурзький Фріндж (Шотландія). Фріндж, у свою чергу, є найбільшим фестивалем театрального мистецтва в світі;

- Міжнародний фестиваль «Золотий лев» $є$ державним плановим фестивалем України, який відбувається щодва роки у м. Львові на базі Львівського академічного духовного театру «Воскресіння»;
- Міжнародний фестиваль в Сібіу, Румунія, третій за обсягом і масштабністю в Свропі після фестивалів у Единбурзі й Авіньйоні;

- Міжнародний театральний фестиваль «Мельпомена Таврії»;

- Pro.Act Fest - перший англомовний театральний фестиваль України. Фестиваль організовано ProEnglish Theatre - англомовним театром-студією та проводиться за підтримки НСТДУ (Національна спілка театральних діячів України) та Центру Леся Курбаса. Цей проект дуже цікавий, тому що мета фестивалю - зробити Україну більш англомовною та театральною. Тим паче якщо в Україні ставитимуться вистави англійською мовою, це дасть поштовх до гастролей на новому рівні.

Безперечно, участь у міжнародних фестивалях сприяє тому, щоб українські театри не опинились у обмеженому, ізольованому від світових тенденцій колі. Перегляд вистав театрів інших країн, мистецтвознавче спілкування та обговорення найактуальніших тем, опанування інноваційних технологій дають усі підстави для дальшого розвитку театральної справи в Україні. Фестивалі можна розглядати також і як майданчик для презентацій аматорських театрів, яких на Україні чимало. Скажімо, Україна бере участь у заходах AITA/IATA (Міжнародної асоціації аматорських театрів), що проводяться в Данії, Індії, Німеччині, Угорщині, Монако.

Можна сказати, що одним 3 наймасштабніших шляхів інтеграції сценографії та театрального мистецтва загалом є Європейська Театральна Конвенція (ЄТК) - це мережа європейських публічних театрів, заснована в 1988 році для сприяння сучасному драматичному театру, підтримки мобільності художників та розвитку мистецького обміну по всій Європі та за її межами. Завдяки театральним проектам ЄТК використовує театр для підтримки міжкультурного діалогу та своєї діяльності, формує європейський культурний простір, пропонуючи доступ до культури для всіх поколінь, та бере участь в обміні найкращими практиками та ідеями між європейськими інституціями, державами-членами та суспільством, організовує зустрічі, інвестує в освітні та навчальні можливості. ЄТК стала найбільшою загальноєвропейською мережею такого типу, що представляє понад 40 театральних колективів у 25-ти країнах, 8000000 глядачів театру, понад 11000 платників податків, зайнятих у державних театрах, тисячі майстрів у більш ніж 20-ти країнах та 16000 виставок і публічних заходів на рік. Крім цього, СТК - це ме- 
режа художніх театральних спілок, що розвиває міжнародні проекти та проекти 3 художньої мобільності $з$ акцентом на багатомовність і художню освіту. Політична ситуація в Україні дає підстави для зміцнення зв'язку ЄТК з театрами і митцями країн, які у нині перебувають в умовах кризи, аби будувати мости та об'єднуватися 3 партнерами мережі ЄТК для побудови тривалих відносин i створення нових професіональних перспектив [12]. У 2016 році ЄТК ініціювала новий проект «Театр Діалогу - Діалог культур: європейське співробітництво зі східноєвропейськими театрами» спільно 3 Staatstheater Braunschweig і у співпраці з українськими та грузинськими театрами.

Не менш важливим шляхом є Опера Свропи одна 3 найбільш впливових міжнародних оперних асоціацій світу, яка сприяє обміну інформацією й театральним досвідом та просуванню опери як інтернаціонального виду мистецтва [11]. Проте, як вже зрозуміло з назви, діяльність асоціації більш вузько спрямована, тому що стосується лише оперних театрів. Сьогодні до асоціації входять три українських театри, зокрема Національна опера України, Київський національний театр оперети та Львівська національна опера, на черзі подання від Харківського національного академічного театру опери та балету імені М. В. Лисенка. Стосовно оперних театрів, де інтеграція відбувається саме через гастролі, асоціація дає можливість обмінюватись досвідом та організовувати гастрольну діяльність. Керівництво здійснює зв'язки 3 імпресаріо інших країн, таких як Італія, Греція, Японія та ін. Виступаючи на конференції «Опера Європа-2017 у Києві. Мистецтво, що об'єднує», директор Національної опери України Петро Чуприна наголосив: «На законодавчому рівні зарубіжна гастрольна діяльність українських театрів не регламентована... кожен 3 нас вибудовує цей напрям діяльності, спираючись на власний досвід...» Співпраця з асоціацією Опера Свропа, допоможе українським оперним театрам чіткіше упорядкувати гастрольну діяльність.

Гастролі українських театрів вимагають від сценографів вирішення багатьох завдань, одне 3 них полягає в тому, що за кордоном - різні сцени і до кожної слід знайти свій підхід. Технічні характеристики сцен диктують свої правила в сценографії. Іноді доводиться відмовлятися від деяких елементів декораційного оформлення, намагаючись не порушити задум художника. Але запозичення досвіду та незвичайних технологічних рішень є важливою складовою інтегрування українських сценографів у європейську сцену.
Спільні театральні міжнародні проекти, які залучають на українську сцену багатьох талановитих митців з різних країн, сприяє розвиткові сучасного українського театрального мистецтва та $\epsilon$ важливим шляхом його інтеграції. Міжнародна творча кооперація відкриває українським театрам нові можливості творчого пошуку та реформації театрального процесу. Насамперед, новий погляд на формування репертуарної політики розширив рамки творчих можливостей колективів з урахуванням сучасних тенденцій і критеріїв розвитку європейського культурного процесу.

Визначною подією для сценографів усього світу є Празький Квадрієнале. Міжнародний конкурсний показ сценографії та театральної архітектури - це найбільший і найпрестижніший у світі захід в такому ключі. Празький Квадрієнале являє собою унікальну платформу для зустрічі театральних культур і художників, пропонуючи їм рідкісну можливість обмінятися досвідом, відкрити для себе нові театральні тенденції й технічні можливості або спробувати нові прийоми роботи у рамках семінарів. Зазначимо, що наші корифеї української сценографії - Давид Боровський, Федір Нірод, Данило Лідер, Свген Лисик, Март Китаєв, Валерій Левенталь - свого часу експонували свої роботи на Празькому Квадрієнале. Головне, чого вчить Квадрієнале, - повна свобода творчого мислення, відмова від будь-яких кордонів, забобонів, стереотипів.

Наразі, після переліку деяких із можливих шляхів інтеграції української сценографії у сценографію світову, потрібно окреслити проблеми, що постають перед митцями та заважають вітчизняним сценографам розвиватися інтенсивніше. Скажімо, щоб скористатися однією з закордонних можливостей, треба робити нестандартні речі, тобто створювати сучасну, нову та цікаву сценографію, бо «театр масових видовищ здатний запропонувати таке розмаїття форм, рівних яким навряд чи можна знайти в будь-якому іншому виді мистецтва» [3]. Але тут постає аспект впливу та залежності художника-сценографа від режисера, від театру, які іноді заважають розвиткові в сфеpi сценографії. Деякі з митців бачать проблему розвитку сучасної сценографії в недостатньому фінансуванні театрів, а фінансування театрів, у свою чергу, залежить від економічної ситуації в країні. Взагалі, фінансовий аспект є першочерговим для сценографів. Реновація освітлювальної техніки, сценічних майданчиків, залучення та опанування новітніх технологій у сфері сценографiї без фінансової підтримки неможливі. Пробле- 
мою розвитку, за словами молодого сценографа Петра Богомазова, є відсутність стартового майданчика для молоді з проектним фінансуванням, наприклад із грантовою системою. Це дуже потрібно, адже молоді спеціалісти не можуть одразу робити проекти на сцені великого театру, їм треба десь напрацьовувати свої уміння, отож це дасть змогу набути досвід.

Крім того, проблема полягає в застарій системі освіти. Потрібні спільні курси - режисерсько-сценографічні, які працюватимуть ще 3 акторськими групами. Також важливо, щоб такі курси мали театральне приміщення, де могли б вільно працювати, тому що сьогдні художники працюють у майстернях та бачать театр, у найкращому разі, з глядацьких місць. За приклад, до якого треба прагнути, Петро Богомазов ставить школу російського сценографа Дмитра Кримова. На думку Богомазова, Кримов використовує незвичну техніку, цікаві методи і підходи до створення сценографії вистави, і те, що він робить, займає перші позиції в світі. «Вони працюють із точністю атмосфери, образу, висловлювання» [7]. Дмитро Кримов викладає в ГІТІСі на кафедрі сценографії, та його творча лабораторія стоїть в авангарді сучасної театральної педагогічної практики.

Таким чином, перспективи розвитку української сценографії можна поділити на два аспекти: перший - творчий - це спілкування із різними сценографами, стартові майданчики, пошук сучасних рішень, взаємодія художника і режисера, театральні фестивалі, мистецькі гранти тощо. I другий - фінансовий, завдяки якому можна допомогти зробити українську сценографію більш сучасною, технологічною, інформаційною та, як наслідок, інтегрованою у світові мистецькі процеси.

\section{Джерела та література}

1. Базанов В. Техника и технология сцены / В. Базанов. - Л., 1976. $-361 \mathrm{c}$.

2. Березкин В. Театр Йозефа Свободы / В. Березкин. - М. : Изобразительное искусство, 1973. - 31 с.
3. Березкин В. Дмитрий Крымов. Книга о лаборатории. Театр художник / В. Березкин/ М : Московский Культурный центр АРТ МИФ, 2012. $-732 \mathrm{c}$.

4. Березкин В. Искусство сценографии мирового театра. Сценографы России: Давид Боровский. Даниил Лидер / В. Березкин. - М., 2008. - Т. 6. - 617 с.

5. Набоков Р.. Сценографія як просторове рішення театру масових видовищ / Р. Набоков // Культура України : зб. наук. пр. - М-во культури України, Харків. держ. акад. культури - Харків. - 2012. - Вип. 38.

6. Олександр Оверчук: «Будь-яка професія в театрі має бути гнучкою» // Кіно-театр. - 2012. - № 4.

7. Смоляков О. Тот самый ГИТИС / О. Смоляков // Алгоритм. - 2004. - С. 40.

8. Електронний pecypc: https://en.wikipedia.org/wiki/ Linocut

9. Електронний pecypc: https://dyvys.info/2017/04/01/ suchasna-ukrayinska-stsenografiya-za-prostoyu-formuloyupostijno-robyty-shhos-nove-foto/

10. Електронний pecypc: https://life.pravda.com.ua/ culture/2009/10/15/28705/

11. Електронний ресурс: https://www.opera-europa.org/

12. Електронний pecypc: https://www.etc-cte.org/

13. Електронний pecypc: http://www.etc-cte.org/https:// dt.ua/CULTURE/yak_zvyazati_rozirvani_nitki_rezhiser_ oleksandr_bilozub_u_bud-yakiy_krayini_ti_chuzhiy.html

\section{References}

1. Bazanov, V.(1976). Tehnika i tehnologiya stseny. - Leningrad, 361 [in Russian].

2. Berezkin, V. (1973). Teatr Yozefa Svobody. - Moscow, Izobrazitelnoe iskysstvo, 31 [in Russian].

3. Berezkin, V. (2012). Dmitriy Krymov. Kniga o laboratorii. Teatr hudozhnik. - Moscow, 732 [in Russian].

4. Berezkin, V. (2008). Iskusstvo stsenografii mirovogo teatra. Stsenografy Rossii: David Borovskiy. Daniil Lider. Moscow, ART MIF, 617 [in Russian].

5. Nabokov, R. Stsenografiya yak prostorove rishennia teatru masovyh vydovyshch (2012). - Harkiv. - Vyp. 38.

6. Overchuk, Oleksandr (2012). Bud' yaka profesiya v teatri mae buty gnuchkou. Kino-teatr. - Kyiv.

7. Smoliakov, O. (2014). Tot samyi GITIS. - Moscow, Algorytm [in Russian].

8. URL: https://en.wikipedia.org/wiki/Linocut

9. URL: https://dyvys.info/2017/04/01/suchasna-ukrayinskastsenografiya-za-prostoyu-formuloyu-postijno-robyty-shhosnove-foto/

10. URL: https://ife.pravda.com.ua/culture/2009/10/15/28705/

11. URL: https://www.opera-europa.org/

12. URL: https://www.etc-cte.org/

13. URL: https://dt.ua/CULTURE/yak_zvyazati_rozirvani nitki_rezhiser_oleksandr_bilozub_u_bud-yakiy_krayini_ti chuzhiy.html 